\title{
Grazing date and frequency effects on prairie sandreed and sand bluestem
}

\author{
PATRICK E. REECE, JOE E. BRUMMER, RUSSELL K. ENGEL, BRIAN K. \\ NORTHUP, AND JAMES T. NICHOLS
}

\begin{abstract}
At the time of the research, authors were Associate Professor, Panhandle Research and Extension Center, University of Nebraska, 4502 Ave. I, Scottsbluff, Neb. 69361, Research Coordinator, Research Technologist, Graduate Student and Professor, West Central Research and Extension Center, University of Nebraska, Route 4, Box 46A, North Platte, Neb. 69101.
\end{abstract}

\begin{abstract}
A 5 year study was conducted during 1988-1992 to quantify the effects of grazing date and frequency on total organic reserves of prairie sandreed [Calamovilfa longifolia (Hook.) Scribn.] and sand bluestem (Andropogon hallii Hack.). Treatments consisted of mid-month grazing periods in (1) June, (2) July, (3) August, (4) October, (5) June and July, (6) June and August, (7) July and August, or (8) June, July, and August. Seasonal stocking rates were equal among treatments and divided equally over multiple grazing periods. Grazing treatments were applied to the same pastures during 4 consecutive years with yearling cattle and 4-7 day grazing periods. Mean tiller weight of etiolated initial-spring growth was used to estimate total organic reserves in the fifth year. Dormant season grazing in October was not different from 4 years of rest for either species. Total organic reserves in prairie sandreed decreased when paddocks were grazed in June or July regardless of the number of grazing periods per treatment. Reserves in sand bluestem were maintained by grazing once in June or August. Rotationally grazing pastures 2 or more times during June-August is least likely to maintain or increase total organic reserves in either species. Multiple grazing periods initiated in June reduced reserves by about $38 \%$ in prairie sandreed and $30 \%$ in sand bluestem. When stocking rates are similar to this study, deferment periods should be longer than $\mathbf{6 0}$ days after grazing in June to avoid measurable reductions in total organic reserves in both species. Periodic deferment of grazing until midAugust or later will be required to maintain simultaneously high levels of reserves in prairie sandreed and sand bluestem.
\end{abstract}

Key Words: etiolated growth, grazing date, grazing frequency, short-duration grazing, rotational grazing, Calamovilfa longifolia, Andropogon hallii

The total of all grazing research efforts in North America represents only a small percentage of potential comparisons among all

\footnotetext{
Appreciation is expressed to Gordon D. Moeller for his many days of technical support in the field and time away from his family.

Research was partially funded by a CSRS grant, Project No. NEB-43-053.

Published as Paper 10959, Journal series, Nebraska Agricultural Research Division. Manuscript accepted 3 June 1995
}

possible grazing strategies. Fundamental questions of when and how many times to graze during the growing season, to achieve specific vegetation management objectives for individual pastures, remain unanswered for many range ecosystems. Grazing research is expensive because of time, labor, and resource requirements. Clipping studies are less expensive. However, clipping at fixed stubble heights disregards seasonal shifts in relative palatability between vegetative and reproductive tillers or among species and the degree of defoliation increases as the growing season progresses (Menke and Trlica 1983, Mullahey et al. 1991). Placing livestock in small paddocks for selected periods of time incorporates selective herbivory and plant competition effects. Information on vegetation response to date and frequency of grazing during the growing season is limited and generally focuses on lengths of grazing/deferment period sequences without regard to specific dates (Heitschmidt et al. 1987, Hart et al. 1988, Gillen et al. 1990, Taylor et al. 1993). The cumulative response of vegetation to partial growing-season deferment periods, repeated over years, has not been reported. Comparisons between dormant-season grazing and single or multiple growingseason grazing periods at equal seasonal stocking rates have not been reported.

This study was part of an effort to provide a broad ecological data base for the development of an array of grazing strategies designed to accomplish specific vegetation management objectives. The objective of this research was to quantify the cumulative effects of date and frequency of grazing on total organic reserves in prairie sandreed [Calamovilfa longifolia (Hook.) Scribn.] and sand bluestem (Andropogon hallii Hack.), key forage species throughout the 4.9 million ha of Nebraska Sandhills and the sandy prairie soils of the northern and central Great Plains (Lodge 1963, Welch 1968, Aase and Wight 1973, GPFA 1986).

\section{Materials and Methods}

Yearling cattle were used to apply grazing treatments to native vegetation on sands range sites during 1988-1991 at the University of Nebraska, Gudmundsen Sandhills Laboratory (GSL) located near Whitman, Nebr. Soils are Valentine fine sands (mixed, mesic Typic Ustipsamments). Paddocks were 
located along the top of a large stabilized sand dune over a distance of $1.4 \mathrm{~km}$ and were similar in species composition (Table 1). Basal area of species was estimated with a modified step-point system described by Owensby (1973). Prior to the study, the location had been grazed at moderate stocking rates during April and May by cow-calf pairs for the past 30 years. All paddocks were in excellent range condition with an average condition score of 92 in 1988.

Grazing treatments consisted of 4 to 7-day, mid-month grazing periods in (1) June, (2) July, (3) August, (4) October, (5) June and July, (6) June and August, (7) July and August, or (8) June, July, and August (Table 2). Treatments were replicated 3 times

Table 1. Average species composition based upon herbage biomass and basal area for 24, 1.0-ha pastures in 1988 at the Gudmundsen Sandhills Laboratory, Whitman, Nebr.

\begin{tabular}{|c|c|c|}
\hline \multirow[b]{2}{*}{ Species $^{1}$} & \multicolumn{2}{|c|}{ Composition } \\
\hline & $\begin{array}{l}\text { Herbage } \\
\text { biomass }\end{array}$ & $\begin{array}{l}\text { Basal } \\
\text { area }^{4}\end{array}$ \\
\hline & \multicolumn{2}{|c|}{$-\%$} \\
\hline Andropogon scoparius Michx. & 31 & 13 \\
\hline Andropogon hallii Hack & 19 & 9 \\
\hline Calamovilfa longifolia (Hook.) Scribn. & 17 & 9 \\
\hline Panicum virgatum $\mathrm{L}$. & 8 & 5 \\
\hline Boutelou hirsuta Lag. & 8 & 16 \\
\hline Boutelouta gracilis (H.B.K.) Lag. ex Griffiths & 4 & 9 \\
\hline Other Warm-season Grasses 2 & 6 & 6 \\
\hline Cool-season Grasses and Grass-like Species ${ }^{3}$ & 2 & 26 \\
\hline Forbs & 5 & 7 \\
\hline
\end{tabular}

Nomenclature follows The Great Plains Flora Association (1986).

${ }^{2}$ Other warm-seasson grasses were Dichanthelittm oligosanthes (Shult.) Gould var. scribnerianum (Nash) Gould, Dichanthelium wilcoxianum (Vasey) Freckmann, Paspalum setaceum Michs, var. stramineum (Nash) D. Banks, Sporobolus cryptandrus (Torr.) A. Gray, and Muhlenbergia pungens Thurb.

'Cool-season grasses were Stipa comata Trin and Rupr., Stipa spartea Trin, Koeleria pyramidata (Lam.) Beav., and Agropyron smithii Rydb. Grass-like species were Carex eleocharis Baily and $C_{y p e n}$ schweinizzii Torr.

${ }^{4}$ Mean total basal area for all perennial plants was $18 \%$.

over 24, 1.0-ha paddocks. Grazing treatments were applied to the same paddocks during 4 consecutive years. Cattle were weighed after an overnight stand without food and water and allocated to treatments by weight. One animal unit (AU) was equal to $454 \mathrm{~kg}$ of yearling cattle. Seasonal stocking rates were set each year at $60 \%$ utilization of current year herbage as estimated in pastures grazed only in June (Table 3 ). Seasonal stocking rates were equal

Table 2. Grazing treatments during 1988-1991 at the Gudmundsen Sandhills Laboratory, Whitman, Nebr.

\begin{tabular}{cccccc}
\hline \hline & \multicolumn{3}{c}{ Date of mid-month grazing periods } & $\begin{array}{c}\text { Percentage of } \\
\text { seasonal stocking }\end{array}$ \\
\cline { 2 - 4 } Treatment & June & July & August & October & rate/grazing period \\
\hline 1 & $\mathrm{X}$ & & & & 100 \\
2 & & $\mathrm{X}$ & $\mathrm{X}$ & & 100 \\
3 & & & & $\mathrm{X}$ & 100 \\
4 & $\mathrm{X}$ & $\mathrm{X}$ & & & 100 \\
5 & $\mathrm{X}$ & & $\mathrm{X}$ & & 50 \\
6 & $\mathrm{X}$ & $\mathrm{X}$ & $\mathrm{X}$ & & 50 \\
7 & $\mathrm{X}$ & $\mathrm{X}$ & & 50 \\
8 & & &
\end{tabular}

${ }^{1}$ Total seasonal stocking rate was divided equally among multiple grazing periods and was equal among treatments within years. Seasonal stocking rates were established at $60 \%$ utilizution of current year herbage in treatment 1 pastures each year (Table 3).
Table 3. Seasonal stocking rates, distribution of precipitation during 1988-1991 and the 30 year average distribution of precipitation at the Gudmundsen Sandhills Laboratory, Whitman, Nebr.

\begin{tabular}{|c|c|c|c|c|}
\hline \multirow[b]{2}{*}{ Year } & \multirow{2}{*}{$\begin{array}{c}\text { Seasonal }^{1} \\
\text { stocking } \\
\text { rate }\end{array}$} & \multicolumn{3}{|c|}{ Precipitation $^{2}$} \\
\hline & & $\begin{array}{c}\text { January- } \\
\text { March }\end{array}$ & $\begin{array}{c}\text { April- } \\
\text { September }\end{array}$ & $\begin{array}{l}\text { October- } \\
\text { December }\end{array}$ \\
\hline & (AUM/ha) & \multicolumn{3}{|c|}{-} \\
\hline 1988 & 1.48 & 105 & 516 & 42 \\
\hline 1989 & 1.11 & 47 & 163 & 33 \\
\hline 1990 & 1.48 & 74 & 369 & 67 \\
\hline 1991 & 1.63 & 111 & 420 & 93 \\
\hline 30 Year Average & & 70 & 420 & 70 \\
\hline
\end{tabular}

One animal unit (AU) was equal to $454 \mathrm{~kg}$ of yearling cattle following an overnight stand without food and water. One animal unit month (AUM) was equal to 30 animal unit days (AUD).

${ }^{2}$ Precipitation data is from the Mullen $21 \mathrm{NW}$ reporting site, located $10 \mathrm{~km}$ northeast of GSL (NOAA 1991).

among treatments and divided equally over multiple grazing periods.

Twenty $0.25 \mathrm{~m}^{2}$ sample areas, each encompassing preceding year stubble of both study species, were covered with $1.0 \mathrm{~m}^{2}$ tents in each pasture and 3 adjacent ungrazed locations, 2-3 April 1992 , before initial spring growth. Tents were constructed of landscape fabric and suspended by 2 wooden stakes $(2.5 \times 5.0 \times$ $30.0 \mathrm{~cm}$ ) placed $50 \mathrm{~cm}$ apart and driven to a remaining height of $15 \mathrm{~cm}$. The perimeter of tents was secured to the soil surface with landscape staples to exclude all light. Tents covered an area about $90 \times 90 \mathrm{~cm}$ which provided a $15-\mathrm{cm}$ wide buffer around the interior $0.25 \mathrm{~m}^{2}$ sample area. Etiolated tillers were clipped at ground level and counted by species, 26-28 May 1992. Etiolated herbage was oven dried at $60^{\circ} \mathrm{C}$ for 48 hours then weighed to estimate dry matter yield. Total etiolated herbage biomass was divided by tiller density for each species in each quadrat to calculate mean biomass of etiolated tillers as a measure of total organic reserves (Reece et al. 1988). Mean tiller weight of etiolated initial-spring growth is a valid measure of total organic reserves when environmental and physiological limitations do not occur. With the exception of drought, growing conditions and activity of meristematic tissue are favorable for etiolated growth in the field during spring.

Experimental units were individual pastures. Mean responses were calculated from quadrat data within each pasture. Data were analyzed as a randomized complete block using the General Linear Models Procedure (SAS 1982). Blocking criterion was based on the relative amount of topographic relief within pastures. When significant effects were detected, the least-squares means procedure within SAS was used to separate means. Differences among means were declared significant at $\mathrm{P} \leq 0.05$.

\section{Results and Discussion}

Annual precipitation ranged from 243 to $663 \mathrm{~mm}$ compared to the 30 year average of $560 \mathrm{~mm}$. Total precipitation during April-September ranged from 163 to $516 \mathrm{~mm}$ compared to the 30 year average of $420 \mathrm{~mm}$ (Table 3). Drought during 1989 may have contributed to measurable effects after 4 years of grazing treatments. Drought is a normal but unpredictable part of the Great Plains environment which can cause changes in species composition. The magnitude and duration of drought-caused 
changes in mid- and tall-grass prairies increase when rangelands are heavily grazed (Albertson et al. 1957).

Mean density of etiolated prairie sandreed tillers for individual pastures ranged from 20 to $72 \mathrm{~m}^{-2}$ and from 16 to $56 \mathrm{~m}^{-2}$ for sand bluestem. Within pastures, density of etiolated tillers under individual tents ranged from 4 to $224 \mathrm{~m}^{-2}$ for prairie sandreed and from 4 to $168 \mathrm{~m}^{-2}$ for sand bluestem.

Although prairie sandreed and sand bluestem tillers generally emerge in May, substantial growth is limited until warmer air temperatures occur in June (Brejda et al. 1989, Hendrickson 1992). Herbage production is generally most rapid from mid-June to mid-July with peak standing crop occurring by 1 August (Gilbert et al. 1979).

\section{Dormant-season Grazing}

The effect of dormant-season grazing in mid-October on total organic reserves was not different from 4 years of rest for prairie sandreed or sand bluestem (Table 4). Freezing temperatures occurred 2 or more times each year before the October grazing period began. More than $80 \%$ of prairie sandreed tillers and all sand bluestem tillers were discolored by frost and considered dormant. If low-quality, dormant-season forage could be used efficiently for livestock production, resting pastures for 12 months or more would be unnecessary unless residual plant material was needed to control erosion, increase retention and infiltration of precipitation, or accomplish other resource management objectives such as enhanced wildlife cover.

\section{Single, Growing-season Grazing Periods}

All single-use, growing-season treatments reduced total organic reserves in prairie sandreed compared to dormant-season grazing (Table 4). A single grazing period in June or July reduced reserves by about $36 \%$. When paddocks were grazed in August, mean organic reserves in prairie sandreed were greater compared to the June or July grazing treatments, but $17 \%$ below dormantseason grazing. Mean reserves for the August grazing treatment were not different compared to rested sites. In contrast to prairie sandreed, total organic reserves in sand bluestem were affected only by the mid-July grazing treatment which reduced reserves by $26 \%$ compared to dormant-season grazing (Table 4 ). Mean levels of reserves in sand bluestem for single grazing periods in June or August were not different from dormant-season grazing.

Table 4. Mean biomass of etiolated prairie sandreed and sand bluestem tillers in spring 1992 after 4 years of grazing treatments at the University of Nebraska Gudmundsen Sandhills Laboratory, Whitman, Nebr.

\begin{tabular}{lcc}
\hline \hline $\begin{array}{l}\text { Grazing } \\
\text { treatment }\end{array}$ & $\begin{array}{c}\text { Prairie } \\
\text { sandreed }^{1}\end{array}$ & $\begin{array}{c}\text { Sand } \\
\text { bluestem }\end{array}$ \\
\hline June & $----($ mg/tiller)- & ---- \\
July & $58.3 \mathrm{c}$ & $55.0 \mathrm{a}$ \\
August & $61.5 \mathrm{c}$ & $44.8 \mathrm{bc}$ \\
October & $78.6 \mathrm{~b}$ & $58.0 \mathrm{a}$ \\
June, July & $94.2 \mathrm{a}$ & $60.8 \mathrm{a}$ \\
June, August & $59.5 \mathrm{c}$ & $44.0 \mathrm{c}$ \\
July, August & $55.7 \mathrm{c}$ & $41.6 \mathrm{c}$ \\
June, July, August & $60.1 \mathrm{c}$ & $53.5 \mathrm{ab}$ \\
Ungrazed & $57.7 \mathrm{c}$ & $42.4 \mathrm{c}$ \\
SE & $80.3 \mathrm{ab}$ & $62.6 \mathrm{a}$ \\
\hline
\end{tabular}

Means within columns followed by the same letter are not significantly different, $\mathrm{P}>0.05$.
Contrasts between prairie sandreed and sand bluestem in response to the mid-June grazing treatment appear to be related to differences in morphology and phenological development. Prairie sandreed tillers are erect, emerge in May and early June, and growing points begin to elevate from late-May to early-June (Brejda et al. 1989, Northup 1993). In contrast, sand bluestem initiates growth later and has fewer elongated tillers than prairie sandreed during the growing season (Brejda et al. 1989). Initial growth of sand bluestem tillers is frequently prostrate to decumbent (Engel 1993, Northup 1993). Growth becomes erect when growing points begin to elevate from late-June to early-July (Gilbert et al. 1979). Frequency and extent of defoliation per tiller and percentage of tillers grazed are controlled primarily by forage allowance (Gillen et al. 1990, Jensen et al. 1990, Hart et al. 1993, Derner et al. 1994). The relatively high stocking rate and stocking densities used in this study resulted in relatively low forage allowance during single, growing-season grazing periods, particularly in June.

Seasonal changes in the concentration of organic reserves in prairie sandreed and sand bluestem are often dynamic. Measurable differences in carbohydrate concentrations may also occur among roots, rhizomes, and stem bases (Perry and Moser 1974). However, defoliation date and frequency and degree of defoliation generally have no measurable effect on the concentration of carbohydrates in plant parts of either species at the end of the growing season (Welch 1968, Engel 1993). Consequently, treatment effects on total organic reserves of prairie sandreed or sand bluestem, as measured by etiolated initial-spring growth in the field, may be primarily the result of biomass differences in roots and/or rhizomes.

The lack of difference in total organic reserves in sand bluestem between August and October grazing treatments was inconsistent with clipping studies at the Gudmundsen Sandhills Laboratory (GSL). Mullahey et al. (1991) reported that clipping plots only in August was detrimental to sand bluestem. In a study concurrent to our grazing study, Engel (1993) reported that clipping sand bluestem plants only in August caused a 24\% reduction in the amount of total nonstructural carbohydrates (TNC) in roots compared to clipping only in October. The change in TNC corresponded to about a $25 \%$ reduction in root weight and length with no change in concentration of TNC in roots. Lack of differences between August and October treatments in our study may have occurred because of differences in grazing intensities among dates. Advanced plant maturity in August may have caused cattle to graze fewer tillers or remove less herbage per clone from both species compared to clipping studies (Northup 1993). Differences in plant maturity may have been the primary reason for reduced organic reserves after grazing in July compared to August. Forage allowance appeared to be similar in mid-July and midAugust, but seed head emergence in prairie sandreed and sand bluestem occurred primarily during late-July and early-August in this study.

\section{Multiple, Growing-season Grazing Periods}

Dividing seasonal stocking rates equally over 2 or 3 , midmonth grazing periods beginning in June reduced total organic reserves by about $38 \%$ in prairie sandreed and $30 \%$ in sand bluestem compared to dormant-season grazing (Table 4). Increasing the deferment period from 25 to about 56 days after grazing in June had no measurable effect on reserves in either species. The effect of 3 growing-season grazing periods at one- 
third seasonal stocking rates each month was not different from either double-grazing treatment initiated in June for either species.

Use of multiple grazing periods during the growing season did not avoid the reductions in organic reserves observed in prairie sandreed when paddocks were grazed only in June at full seasonal stocking rates (Table 4). While reserves in sand bluestem were maintained with a single grazing period in June, all multiplegrazing treatments beginning in June reduced total organic reserves. In contrast, Mullahey et al. (1991) concluded that defoliation in June and August was optimal for sand bluestem based on a 3-year clipping study. The positive response under clipping may have been caused by a reduction in competitive stress from associated species because all plants in the quadrat area were defoliated whereas plants were selectively defoliated in the grazing study.

Grazing at one half seasonal stocking rates in July and August, compared to grazing only in July at full seasonal stocking rates, did not avoid reductions in organic reserves in prairie sandreed (Table 4). Total organic reserves in sand bluestem for the July and August treatment were intermediate between grazing only in July or only in August. Cumulative negative effects of the July and August treatment on prairie sandreed may have reduced competitive stress on sand bluestem.

The greater tolerance of sand bluestem to growing-season grazing treatments than prairie sandreed was unexpected. High levels of grazing preference for prairie sandreed and sand bluestem were maintained by yearling cattle over a wide range of forage quality and quantity in this grazing study (Northup 1993). Additionally, Burzlaff (1971) observed that crude protein concentration and in vitro dry matter digestibility of current year tillers, collected at 2 week intervals from June through October, were consistently higher for sand bluestem than for prairie sandreed or little bluestem [Schizachyrium scoparium (Michx.) Nash]. Over years, grazing treatments may have reduced root and rhizome biomass in prairie sandreed. Welch (1968) observed that seasonal increases in carbohydrate concentration began in prairie sandreed roots in mid-June and in rhizomes in mid-July. Most reproductive tillers in prairie sandreed originate from buds at the end of rhizomes (White 1977). Reproductive tillers have a negative effect on grazing preference (Northrup 1993). Reductions in rhizome biomass may have reduced the percentage of reproductive tillers and increased grazing preference for prairie sandreed. White (1977) also observed that when soil moisture was deficient during the growing season, only a small number of prairie sandreed tillers became reproductive. Limited development of reproductive tillers under drought conditions in 1989 (Table 3) may have resulted in a greater percentage of tillers grazed and greater degree of defoliation per clone of prairie sandreed than sand bluestem.

\section{Conclusions}

Historically, sand bluestem has been used as a key plant species when assessing grazing management on upland range sites in the Nebraska Sandhills. However, prairie sandreed was susceptible to reductions in organic reserves over a longer period of time than sand bluestem. If total organic reserves in this study were directly related to root biomass and length, summer grazing has a greater potential to reduce herbage production for prairie sandreed than for sand bluestem. Deep, extensive root systems are critical for moisture use in sand soils where water infiltration rates are high and water holding capacity is low. Prairie sandreed may be a better key species than sand bluestem.

Effects of selective herbivory must be considered in the development of grazing strategies. Results of this grazing study corresponded only in part with the response of prairie sandreed and sand bluestem to clipping treatments (Sims et al. 1973, Mullahey et al. 1991, Engel 1993). In addition to selective herbivory, measurable differences in forage allowance occurred among grazing periods at equal stocking rates during June-August because of progressive increases in current-year standing crop. Consequently, it may be necessary to quantify grazing date by stocking rate interactions for June and July before rotational grazing strategies can be optimized at moderate to heavy seasonal stocking rates.

It has been recommended that livestock movement under rotational grazing should be directly related to rate of plant growth to avoid regrazing tillers during a grazing period (Savory 1988). Use of this criterion implies that date of grazing is not significant or that negative effects of grazing during critical dates will be resolved by progressively altering the sequence of pasture use over years. However, unless the number of pastures is large, rapid movement of livestock among pastures when plants are growing rapidly increases the opportunity for animals to regraze plants during successive grazing periods. Annual changes in the order of pasture use should be based on an understanding of how date and frequency of summer grazing affect Sandhills vegetation. Reversing the sequence of pasture use during alternating years increases the possibility of measurable reductions in total organic reserves for both species in the middle pastures. Shifting the sequence of grazing by one pasture each year in a large set of pastures may allow prairie sandreed or sand bluestem to be grazed at critical times for several consecutive years. Under stocking rates similar to this study, summer grazing strategies will not be mutually beneficial for prairie sandreed and sand bluestem without periodically deferring grazing until mid-August or later.

Dividing seasonal stocking rates equally over multiple grazing periods during the growing season was counter productive and reduced total organic reserves in both species when the first grazing period occurred in mid-June. This study supports the conclusion presented by Taylor et al. (1993) that increased number of grazing periods does not promote secondary succession as effectively as fewer grazing periods with longer deferment and longer grazing periods at the same stocking rate. Under environmental conditions similar to our study, more than 60 days of deferment would be required after grazing in June when the average stocking rate in Junc is $\geq 0.70$ AUM ha ${ }^{-1}$.

\section{Literature Cited}

Aase, J.K., and J.R. Wight. 1973. Prairie sandreed (Calamovilfa longifolia): Water infiltration and use. J. Range Manage. 26:212-214.

Albertson, F.W., G.W. Tomanek, and A. Riegel. 1957. Ecology of drought cycles and grazing intensity on grasslands of the central Great Plains. Ecol. Mono. 27:27-44.

Brejda, J.J., L.E. Moser, and S.S. Waller. 1989. Rhizome and tiller development of three Nebraska Sandhills warm-season grasses. p. 211-215. In: T.B. Bragg and J. Stubbendieck (eds.), Proc. Eleventh North Amer. Prairie Conf., Lincoln, Nebr. 
Burzlaff, D.F. 1971. Seasonal variations of the in vitro dry-matter digestibility of three Sandhill grasscs. J. Rangc Manage. 24:60-63.

Derner, J.D., R.L. Gillen, F.T. McCollum, and K.W. Tate. 1994. Little bluestem tiller defoliation patterns under continuous and rotational grazing. J. Range Manage. 47:220-225.

Engel, R.K. 1993. Root and shoot responses of sand bluestem to defoliation. Ph.D. Diss., Univ. of Wyoming, Laramie, Wyo.

Gilbert, W.L., L.J. Perry, Jr., and J. Stubbendieck. 1979. Dry matter accumulation of four warm season grasses in the Nebraska Sandhills. J. Range Manage. 32:52-54.

Gillen, R.L., F.T. McCollum, and J.E. Brummer. 1990. Tiller defoliation patterns under short duration grazing in tallgrass prairie. J. Range Manage. 43:95-99.

Great Plains Flora Association. 1986. Atlas of the flora of the Great Plains. T.M. Barkley (ed.). Iowa State Univ. Press, Ames, Iowa.

Hart, R.H., M.J. Samuel, P.S. Test, and M.A. Smith. 1988. Cattle, vegetation, and economic responses to grazing systems and grazing pressurc. J. Range Manage. 41:282-286.

Hart R.H., S. Clapp, and P.S. Test. 1993. Grazing strategies, stocking rates and frequency and intensity of grazing on western wheatgrass and blue grama. J. Range Manage. 46:122-126.

Heitschmidt, R.K., S.L. Dowhower, and J.W. Walker. 1987. 14- vs. 42- paddock rotational grazing: aboveground biomass dynamics, forage production, and harvest efficiency. J. Range Manage. 40:216-223.

Hendrickson, J.R. 1992. Developmental morphology of two Nebraska Sandhills grasses and its relationship to forage quality. M.S. Thesis, Univ. of Nebraska, Lincoln, Nebr.

Jensen, H.P., R.L. Gillen, and F.T. McCollum. 1990. Effects of herbage allowance on defoliation patterns on tall grass prairie. $\mathrm{J}$. Range Manage. 43:401-406.

Lodge, R.W. 1963. Complementary grazing systems for Sandhills of the northern Great Plains. J. Range Manage. 16:240-244.
Menke, J.W., and M.J. Trlica. 1983. Effects of single and sequential defoliations on the carbohydrate reserves of four range species. J. Range Manage. 36:70-74.

Mullahey, J.J., S.S. Waller, and L.E. Moser. 1991. Defoliation effects on yield and bud and tiller numbers of two Sandhills grasses. J. Range Manage. 44:241-245.

National Oceanic and Atmospheric Administration. 1991. Climatological data (Nebraska). Asheville, N.C.

Northup, B.K. 1993. Utilization of native forages of the Nebraska Sandhills by yearling cattle. Ph.D. Diss., Univ. of Nebraska, Lincoln, Nebr.

Owensby, C.E. 1973. Modified step-point system for botanical composition and basal cover estimates. J. Range Manage. 26:302-303.

Perry, L.J., Jr., and L.E. Moser. 1974. Carbohydrate and organic nitrogen concentrations within range grass parts at maturity. J. Range Manage. 27:276-278.

Reece, P.E., R.P. Bode, and S.S. Waller. 1988. Vigor of needleandthread and blue grama after short duration grazing. J. Range Manage. 41:287-291.

SAS. 1982. User's guide: Statistics. SAS Inst., Inc., Cary, N.C.

Savory, A. 1988. Holistic resource management. Island Press, Covelo, Calif.

Sims, P.L., R.K. Lang'At, and D.N. Hyder. 1973. Developmental morphology of blue grama and sand bluestem. J. Range Manage. 26:340-344.

Taylor, C.A., Jr., T.D. Brooks, and N.E. Garza. 1993. Effects of short duration and high-intensity, low-frequency grazing systems on forage production and composition. J. Range Manage. 46:118-121.

Welch, T.G. 1968. Carbohydrate reserves of sand reedgrass under different grazing intensities. J. Range Manage. 21:216-220.

White, L.M. 1977. Perenniality and development of shoots of 12 forage species in Montana. J. Range Manage. 30:107-110. 